\title{
Empirically Investigating Saudi Arabian Accountants' Readiness to Implement IAS 2
}

\author{
Muna Ali Al-Mousa \\ Master of Accountancy, Saudi Arabia \\ Khalid Rasheed Al-Adeem \\ $\mathrm{PhD}$, Assistant Professor of Accountancy, King Saud University, Riyadh, Saudi Arabia
}

\begin{abstract}
This study focuses on practicing accountants in Saudi Arabia to examine their readiness to adopt the mandatory International Financial Reporting Standards (IFRS). More specifically, it investigates the International Accounting Standard for Inventories, an indicator for accountants' understanding of IFRS requirements. To do so, we conduct an online questionnaire survey, which reveals that $52.27 \%$ accountants may not be ready for IFRS implementation. The lack of knowledge about certain IAS 2 requirements raises further concerns about accountants' readiness to implement more complicated IFRS, some of which have no comparable local financial accounting standards. These findings draw attention to the effectiveness of IFRS training courses. Further, $57.20 \%$ accountants, all of whom reviewed the Saudi Organization for Certified Public Accountants' (SOCPA) website, provided appropriate answers, indicating SOCPA's significant contribution toward the spreading of awareness and knowledge about IFRS. Our findings have implications for practitioners and accounting regulators as well as bodies responsible for standardizing accounting practices in Saudi Arabia. In particular, they suggest steps necessary to increase accountants' readiness for IFRS adoption, which became mandatory since January 1, 2017, for all listed companies. In conclusion, this study serves as a foundation for future research on the topic, which can be extended to the realm of auditors, and obstacles confronting accountants in IFRS implementation.
\end{abstract}

Keywords: International Financial Reporting Standards, IFRS adoption, Readiness, Inventories, Practicing accountants, Accounting knowledge.

JEL Classification: F36, F69, H83, M41, M42, O47.

(C) The Authors, 2017. This article is published with open access at ARMG Publishing.

\section{Introduction}

Over the past years, the world has witnessed a leap in technology and communication, which has considerably impacted the world economy, particularly, the capital markets. These dramatic changes have made possible effective investments in global corporations compared to locally available options. Today, investors have access to various means of communication to facilitate their investment decisions. A key factor in identifying the most efficient means of wealth and savings investments is reliable financial information.

Accounting is a main source for financial and non-financial information, and thus, global accounting bodies and organizations bear the responsibility of leading the development and improvement of information provided to investors and other users. Accounting has gained widespread appreciation and importance with the emergence of publicly held corporations (Al-Adeem, 2017a; Al-Adeem and Fogarty, 2010; Merino 1993; Previts and Merino, 1998). In fact, the field has developed and continues to do so in response to dynamic business needs (Al-Adeem, 2017a; Chatfield 1977; Cowan, 1968; DR Scott, 1926; Hopwood, 1987; Littleton, 1943). A notable example is the movement toward a unified accounting system in response to investors' present-day needs ( العديم [Al-Adeem], 2015).

International Financial Reporting Standards (IFRS) are being implemented worldwide for various reasons. Most importantly, global acceptance of a common accounting language will facilitate cross-border investments and the flow of capital (Erickson et al., 2009). Investors, including institutional ones, are among beneficiaries of high-quality financial statements (Florou and Pope, 2010). The increase in the number of investors in global financial markets has also encouraged the proposal and widespread adoption of IFRS (Kotlyar, 
2008). Li (2013) empirically shows that IFRS adoption eases the integration of capital markets. A factor contributing to the capital movement expanding the international exploration of new investment opportunities is globalization (Yilmaz and Gelmedi, 2012, p.624). Advanced investors are expected to largely accrue from the benefits of the switch to IFRS (Kosarkoska and Mircheska, 2012).To this effect, Florou and Pope (2012) find that institutional holdings increase for mandatory IFRS adopters.

Accounting researchers have debated a single set of world accounting standards (Ball, 2006; Buchana, 2003) and "one accounting, one world" (Erickson, 2009). Scholars have also reviewed IFRS credibility and reliability (Alali and Cao, 2010). Accounting studies on IFRS and its adoption vary by aim and objective. While some illustrate a specific international standard (e.g., Monday, 2009), some others examine the effect of IFRS adoption and convergence on accounting quality (e.g., Barth et al., 2008; Chua et al., 2012; Elias, 2012; Zeghal et al., 2012) as well the quality of financial statement information (Iatridis, 2010). Other studies investigate the international politics of accounting standards (e.g., Königsgruber, 2010; Posner, 2009, 2010) and IFRS harmonization (e.g., Ramanna, 2013 ${ }^{1}$ ) and their relevance (Alali and Foote, 2012; Tyrrall et al., 2007). Some accounting research sheds light on the advantages of a unified accounting system dictating the worldwide preparation of financial statements. The perceived benefits of such a system include comparability, reduced capital cost, and corporate cost saving in preparation of financial statements. Other accounting researchers, however, are skeptical (العديم [Al-Adeem], 2015; Karim, 2001) or even critical (e.g., Lehman, 2005). The accounting literature discusses the possibility of IFRS representing challenges confronting the will of nations and societies interested in implementing them (e.g., Odia and Ogiedu, 2013, p.394). However, practicing accountants' readiness to implement IFRS is an obstacle that is yet to be fully discussed in the literature. Arguably, even if such a research question were investigated in other societies, the readiness of accountants varies by nation and thus, is worth exploring among practicing accountants in Saudi Arabia.

This study explores the readiness of accountants at a time when a nation is about to converge its national accounting standards to IFRS; it examines the readiness of practicing accountants in Saudi Arabia. Saudi Arabia has a significant economic position in the Arabian Gulf Region, the Middle East, and other Arab countries. It is also a member of the economic group of twenty (G-20) and considered one of the most important sources and price setters of global energy. Given its large volume of international trade and financial resources, effective management of foreign investments and foreign exchange reserves, and disciplined supervision of the banking sector, Fitch, the international ratings company, has confirmed the durability of Saudi Arabia economy and its financial strength and maintained its credit rating at -AA. ${ }^{2}$ According to recently published official statistics, Saudi Arabia's foreign direct investment numbers at more than 16.4 billion USD. ${ }^{3}$ Arguably, the decision of IFRS convergence by Saudi Arabia and its regulating bodies may be in alignment with the nation's economic development and progress.

To investigate practicing accountants' readiness regarding the IFRS implementation, we analyze responses to a questionnaire that is based on their understanding of IAS 2 and differences between IAS 2 and the Saudi Inventory Standard (AS-005). AS-005 is one of the oldest standards issued and implemented by the Saudi Organization for Certified Public Accountants (SOCPA). The findings reveal that a proportion of accountants lack knowledge about certain IAS 2 requirements, some of which may have no comparable local financial accounting standards, and this can be considered reflective of their readiness to implement more complicated IFRS. This suggests that if Saudi Arabian accountants currently find the implementation of IAS 2 challenging, they are likely to face even more difficulties in applying other standards, especially new ones that do not have equivalent local standards, for example, those for fair value (IFRS 13), financial instruments (IFRS 9), and agriculture (IFRS 41).

The remainder of this paper is organized as follows. Section 2 is a review of the literature on IFRS adoption and raises the question of whether practicing accountants in Saudi Arabia are ready for the mandatory adoption of IFRS. We use IAS 2 as an indicator to measure their overall readiness. Section 3 explains the method used

\footnotetext{
${ }^{1}$ Several accounting writers have commented on this paper (see Haas, 2013; Madsen, 2013; Saito, 2013).

${ }^{2}$ Kingdom of Saudi Arabia and its influential role in the global economy, a report published by [AlMaina] daily newspaper.

Available at http://www.al-madina.com/node/561116 (Accessed August 26, 2017).

${ }_{3}^{3}$ Private sector participation in investment exceeds $\$ 79$ billion, a report published by [Okas] daily newspaper. Available at http://www.argaam.com/article/articledetail/452252/ (Accessed September 6, 2017)
} 
to address this research question and presents a comparative study of IAS 2 and AS-005. Section 4 discusses the results. Section 5 concludes with limitations and a direction for future research.

\section{Literature Review}

\subsection{History and Overview of International Accounting Standards}

Since its founding in 1973, the main objective of the board of the International Accounting Standards Committee (IASC) has been to develop a single set of high-quality international accounting standards to substitute national ones (Odia and Ogiedu, 2013). Between 1973 and 2001, the IASC set up the IAS and on April 1, 2001, it became IASB, which continues to set standards for international accounting (Camfferman and Zeff, 2007; Parker, 2014). During its first meeting, IASB adopted existing IAS and Standing Interpretations Committee (SIC) standards and it continues to conduct intensive work on the development of standards, which have come to be known as the International Financial Reporting Standards (IFRS) (for more, see Parker 2014). In 2002, the Financial Accounting Standard Board (FASB) and IASB agreed on a memorandum of understanding for the convergence of the US GAAP and IFRS, ${ }^{1}$ although it remains to be implemented despite the various declared deadlines.

Over the past two decades, substantial research has been conducted on various IFRS aspects. The following sub-sections detail the harmonization and institutional framework, IFRS benefits and challenges, reasons for IFRS adoption, and finally, the impact of IFRS on financial statements and accounting disclosures.

\subsection{Harmonization and Institutional Framework}

The need for accounting harmonization has been widely attributed to capital market globalization (Quigley [2007] as cited in Odia and Ogiedu [2013]) and the emergence of multinational corporations ( العديم [AlAdeem], 2015). Investors seek golden investment opportunities all over the world and companies do so for capital in capital markets, crossing national borders in search of the lowest possible cost. The demand for transparency in a company's financial statements and relevant, reliable, and understandable information has increased by investors, lenders, and numerous other users of financial information to make rational decisions. Narrowing down dissimilarities in the accounting systems of individual countries should reduce the costs of compiling financial data from numerous adoptions considered plausible by investors (Yilmaz and Gelmedi, 2012, p.621). Juhmani's (1998) empirical study of the Gulf Cooperative Countries reveals that adopting to international accounting standards enhances the information content of financial statements. This outcome can be achieved by reducing or eliminating differences in accounting policies and principles between countries.

A country's accounting and disclosure system is part of its financial system, which in turn is a component of the country's institutional infrastructure. Each country has its own institutional framework as a result of the consistency between its accounting system and related elements that compose the institutional framework (Obazee [2007] as cited in Odia and Ogiedu [2013]). However, such independent institutional frameworks have raised concerns about the adoption and implementation of IFRS in various countries (e.g., العديم [AlAdeem], 2015; Belkaoui, 1995; Irvine and Lucas, 2006; Lehman, 2005; Okabol and Tinker, 1990; Ordelheide 2004; Tinker, 2004). Despite the benefits of IFRS, countries willing to adopt IFRS continue to face challenges.

\subsection{Reasons for IFRS adoption}

The expected benefits of IFRS adoption, including the lower susceptibility to political pressures compared to national standards (Choi and Meek [1999] as cited in Odia and Ogiedu [2013]), have fueled countries' willingness to move toward IFRS implementation. To date, 131 jurisdictions require or permit IFRS for domestically listed companies (IASB, 2017) ${ }^{2}$.

IFRS adoption is expected to benefit investors and other users of financial statements by reducing the costs of comparing alternative investments and increasing information quality (Ball, 2006). In addition, IFRS decreases obedience costs by eradicating the need to reconcile and decrease capital cost (Kotlyar, 2008). In addition to investors, companies benefit from adopting IFRS through increased financing (Bradshaw, 2010).

\footnotetext{
${ }^{1}$ http://www.ifrs.org/Use-around-the-world/Global-convergence.

${ }^{2}$ Available at https://www.iasplus.com/en/resources/ifrs-topics/use-of-ifrs; (accessed on 8/2/2017).
} 
In general, multinational corporations prefer using a unified strategy to deal with various stakeholder demands. When faced with "customers, tastes, or cultural or religious differences," multinationals corporations decide and strategically work toward unifying global consumer tastes, enabling them "to sell the same things in the same way everywhere" without being governed by domestic uniqueness (Clark, 1996, p.304). A similar strategy should be applied to the preparation of financial statements (العديم [Al-Adeem], 2015). IFRS adoption saves multinational corporations the expense of preparing more than one set of accounts for different national jurisdictions (Irvine, 2008). Thus, companies that have a high number of international activities and transactions and a presence in various continents are expected to benefit from convergence of their standard with IFRS. Empirical evidence suggests that IFRS adoption is positively associated with capital market integration (Li, 2013). In other words, companies involved in foreign investment activities can benefit from the convergence given the increased comparability of a set of accounting standards.

Rita et al. (2012) argue that the higher the information quality resulting from IFRS adoption or convergence, the more enhanced the comparability. Arguably, "the comparability improvement is more likely to occur among firms from similar institutional environments than among firms from different institutional environment" (Rita et al., 2012, p.1787). Cascino and Gassen (2012) evidence the global effects of mandatory IFRS adoption on the comparability of financial accounting information. However, cross-country differences in accounting quality might remain despite the IFRS adoption, possibly because of the dependence of accounting quality on a firm's overall institutional setting (Soderstrom and Sun, 2007).

Developing countries in favor of IFRS adoption appear to share characteristics such as high economic growth rates, high education level, and a common legal system (Zehri and Chouaibi, 2013). According to economic network theory, it is likely that IFRS adoption will increase with the number of IFRS adopters in a geographical region and among its trade partners (Ramanna and Sletten, 2009).

In sum, there are numerous revealed and unrevealed reasons as well as complicated factors that lead a country's adoption of IFRS. A probable, visible, and common reason to do so is the more reliable financial information that promotes better decision making among users and enhances cross-country information comparability.

\subsection{Effects of Adopting IFRS on Financial Statements and Accounting Disclosures}

According to the IASB framework, "[t]he objective of financial statements is to provide information about the financial position, performance and changes in financial position of an entity that is useful to a wide range of users in making economic decisions" (IAS 1, Para. 9). A financial statement should aim to achieve relevance, faithful representation, comparability, and understandability (IFRS 1, Para. BC8).

Agyei-Mensah (2013) finds that the quality of financial reports has significantly improved following the adoption of IFRS owing to more reliable financial information disclosure. Studies find that IFRS adoption or convergence is associated with accounting quality in Australia (Chua et al., 2012; Elias, 2012) and the France (Zéghal et al., 2011). Adopting IFRS affects the financial position of a publicly reporting accounting entity. Stent et al. (2010) examine the impact of IFRS adoption on the financial statements of 56 listed companies in New Zealand and find that their liabilities were most affected with an increase of $75 \%$, followed by equity with a $57 \%$ decrease. While income taxes and employee benefits are the main reasons for increased liabilities, financial instruments are mainly responsible for growth in assets. Therefore, IFRS adoption could considerably influence the financial position of listed firms and their financial statements, which in turn impact their users.

\subsection{IFRS Benefits and Challenges}

The global adoption of IFRS could yield several potential benefits, including better financial information for shareholders and regulators, enhanced comparability (Cascino and Gassen. 2012; Erickson et al. 2009; Yip and Young, 2012), improved transparency of results (Buchanan, 2003), increased ability to secure cross-border listing (Li, 2013), better management of global operations, and decreased capital cost (Kotlyar, 2008).

However, these benefits are accompanied by challenges. For instance, a single set of accounting standards cannot reflect all differences in national business practices by various institutions and cultures. Cultural (e.g., Ding et al. 2005; Gray, 1988), political (e.g., Ramanna, 2013), and business differences may also continue to pose significant obstacles in the progress towards a unified, global financial communication system (see Odia and Ogied, 2013). 
Reviewing prior studies, Odia and Ogied (2013, p.394) summarize challenges confronting the worldwide adoption of IFRS. First is IASB funding, staffing, and governance structure as well as consistent adoption. Second is the presence of various versions of IFRS applications with inconsistent IASB prescriptions, which creates the need for a regulatory review and enforcement mechanism. The interpretation of principle-based accounting such as IFRS may vary by nation and society (Alali and Cao, 2010) and this may limit the claimed comparability advantage of a single set of accounting standards (العديم [Al-Adeem], 2015)). Third is the possibility of an auditor's failure to express an opinion about IFRS compliance or non-compliance (Cairns [2001] as cited in Odia and Ogied [2013]). Fourth is the increased need for training and education for accountants, auditors, investors, drafters, and users of financial statements (Odia and Ogied, 2013). Thus, by examining the readiness of practicing accountants in Saudi Arabia, this study can help determine the need for more training and education for IFRS implementation.

\subsection{IFRS Adoption: SOCPA's Experience}

In Saudi Arabia, the adoption of international accounting standards was approved by the SOCPA board during the tenth meeting of the sixth session held on $26.03 .1433 \mathrm{H}$ (February 18, 2012). The decision was made following a careful deliberation by a steering committee favoring the transition to international standards. Some experts have expressed critical views of SOCPA's actual mechanism regarding IFRS adoption (seest [Al-Adeem], 2017, pp.547-549). To achieve the best results and consequently, realize high-quality financial reports ${ }^{1}$, the steering committee emphasized that SOCPA follow an elaborate plan that accounts for environmental and economic factors in Saudi Arabia. In addition, this process should be a gradual one such that stakeholders have adequate time to professionally and technically approach the transition.

It is noteworthy that up to period in which the IFRS transition was decided, SOCPA issued domestic and Saudi standards comprising 22 financial accounting standards, 15 auditing standards, and various accounting and auditing interpretations and professional opinions. SOCPA followed a firm approach and referenced similar procedures in the United States and United Kingdom and other international standards. IFRS has always been an option available to accountants in Saudi Arabia, particularly in the absence of domestic standards, to address problems faced by accounting entities. SOCPA's decision to adopt IFRS requires intensive efforts and here, effective accountant training is of crucial importance.

\section{Research Method}

The research methods employed in accounting studies attempting to address IFRS-based research questions tend to differ. For example, some studies survey companies on their perceptions about and experiences with IFRS adoption (e.g., Haller and Wehrfritz, 2013; Joshi et al., 2008). Some others conduct a content analysis of letters submitted to accounting professional bodies in Japan and the United States regarding IFRS implementation in their respective nations (Holder et al., 2013; Tsunogaya, 2016).

\subsection{Research Instrument for Data Collection}

This study investigates the readiness of accountants in Saudi Arabia prior to the official mandating of IFRS, particularly International Accounting Standard for Inventories (IAS 2). All accounting entities, even manufacturing and merchandizing firms, are affected by IAS 2. In 1997, the SOCPA issued its first financial accounting standards that dealt with the measurement, reporting, and disclosing of inventories (Saudi Standard for Inventories (AS-005)). Accountants in Saudi Arabia have been implementing AS-005 for two decades. Another factor motivating this study on AS-005 is the suggestion by Assistant Secretary General Dr. Abudlrahman AL-Razeen that IAS 2 is an international accounting standard that is expected to significantly impact corporate financial statements in Saudi Arabia.

Theoretically, practicing accountants in Saudi Arabia should be sufficiently aware of AS-005 requirements to identify differences from IAS 2. Any lack of knowledge about the effects of convergence to IAS on accounting treatments for inventories may be generalized to IFRS as a whole. Such a gap, if empirically found, raises a serious question and concern about the readiness to implement more complicated IFRS, particularly since

\footnotetext{
${ }^{1}$ SOCPA Project for Transition to International Accounting \& Auditing Standards, available via: http://socpa.org.sa/Socpa/AboutSocpa/SOCPA-Projects.aspx?lang=en-us.
} 
Saudi standards issued by SOCPA lack comparable ones, for example, IFRS 9 (financial instruments), IFRS 41 (agriculture), and IFRS 13 (fair value).

A questionnaire was designed for this study to gain insight into the readiness of practicing accountants in Saudi Arabia. The questions in the survey were carefully designed on the basis of an analytical comparison between IAS 2 and AS-005. In addition, literature and reports, although unpublished, by experts and submitted to SOCPA were referenced. SOCPA hired experts to inform its committee about those working to converge its national standards with IFRS. The questionnaire employed in this study,comprise a total of 11 technical questions were asked. Respondents were required to have knowledge about both IAS 2 and AS-005 but could declare ignorance about any question and mention in the questionnaire that they did not know the answer by choosing the corresponding option. Accounting studies in Saudi Arabia employ a similar approach to designing questionnaires with the objective of investigating practicing accountants' readiness regarding the implementation of international standards that have comparable (e.g., Alhamoudi, 2017) and non-comparable (e.g., [Almowash] 2015, Alsalamah, 2017) equivalents.

The following brief comparison presents the basis used to construct technical questions related to IAS 2 requirements. Such questions must be directed to Saudi Arabian accountants who are subjects of the study. The survey employed in this study is presented in the Appendix. Correct answers indicate that accountants are ready for the IAS 2 implementation. Since a majority of the accountants in Saudi corporations are arguably Arabs, the survey was conducted in Arabic for better understanding. Similarly, SOCPA presented Saudi standards and tested accountants certified to practice public accounting in Arabic. It is assumed that using Arabic, the primary language in Saudi Arabia, may encourage participation.

\subsection{Comparison of IAS 2 and AS-005}

The comparison between the International Accounting Standard for Inventories, IAS 2, and the Saudi Accounting Standard for Inventories, AS-005, reveals the extent to which IAS 2 is more detailed, clear, and most importantly, comprehensive. First, in terms of scope, IAS 2 excludes work in progress arising from under construction contracts, financial instruments, and biological assets related to agricultural activities and products at the time of harvest as they are included in other international accounting standards. In addition, the measurement requirements of IAS 2 (Para. 3) do not apply to inventories held by producers of agricultural and forest products, agricultural produced post-harvest,and minerals and mineral products because these inventories are measured in net realizable value according to the well-established practices in their respective industries. Further, commodity broker and traders measure their inventories at fair value less costs to sell (including the explanation related to them IAS 2). On the other hand, AS-005 (Para. 102) excludes fixed assets of normal facility operations that are written-off and deposited in the depot for sale.

In the definitions of IAS 2 (Para. 6), inventories are assets held for sale in the ordinary course of business, while these important points are absent in AS-005 (Para. 128). Moreover, the definition of fair value in IAS 2 (Para. 6) is not stated in AS-005. Nevertheless, the definition of the net realizable value in IAS 2 (Para. 6) is similar to that of market price in AS-005, although IAS 2 (Para. 6) refers to it as estimated selling price and AS-005 (Para. 140) calls it real or estimated selling price. Similarly, many definitions mentioned in AS-005 are explained in IAS 2, such as the definition for the normal capacity of production facilities (IAS 2, Para. 21).

Next, both IAS 2 (Para. 9) and AS-005 (Para. 115) state that inventories shall be measured at the lower of cost and net realizable value, which is termed "market value" in AS-005. In addition, IAS 2 (Para.10-13 and 15) and AS-005 (Para. 106-109) agree on the cost of purchase, cost of conversion, and several other costs such as non-production costs incurred to bring inventories to their present location and condition as part of inventory costs.

IAS 2 (Para. 13 and 14) offers a broader explanation of conversion cost and the situation of producing more than one product and discusses the numerous issues overlooked in AS-005, which are discussed as follows.

To the effect conversion cost, IAS 2 (Para. 13) states that the amount of fixed overhead allocated to each production unit should not increase as a result of low production or an idle plant and the unallocated overhead

\footnotetext{
${ }^{1}$ This section has benefited from two documents shared by Mr. Suliman Abutayeh (2013) and Dr. Khalid Al-Adeem (2013); both documents were prepared for SOCPA during the consultancy assignments.
} 
should be recognized as an expense in the period in which it is incurred. In addition, IAS 2 (Para. 13) explains that during periods of abnormally high production, fixed overhead allocated to each production unit should be decreased because inventories will not be measured above cost and variable production overheads are allocated to each production unit on the basis of actual use of production facilities. IAS 2 (Para. 14) discusses the situation in which a production process may simultaneously result in more than one product, and thus, the conversion cost cannot be separately identified. In this case, cost will be allocated to products on a rational and consistent basis. Nevertheless, IAS 2 (Para. 16-20) offers examples of costs excluded from inventories costs and recognized as an expense for the period in which they are incurred, such as inventories purchased on deferred settlement terms, inventory costs for a service provider, and cost of agricultural product harvested from biological assets.

Both IAS 2 (Para. 21 and 22) and AS-005 (Para. 122 and 123) permit the standard cost and retail methods as techniques for cost measurement if the results approximate cost. However, it is noteworthy that in IAS 2 (Para. 21), standard cost must be regularly reviewed and accordingly restated. IAS 2 (Para. 22) states when the retail method must be used. To the effect of cost formulas, IAS 2 (Para. 23 and 24) are similar to AS-005 (Para. 112), although the former offers more detailed explanations. IAS 2 (Para. 23 and 24) explain that the cost of items that are not ordinarily interchangeable and goods or services produced and segregated for specific projects shall be assigned by specifically identifying their individual costs.

A major difference between the two standards is evident in IAS 2 (Para. 25-27); that is, the costs of inventories other than those in IAS 2 (Para. 3) shall be assigned using first in, first out (FIFO) or weighted average cost formula. Furthermore, IAS 2 (Para. 25) asserts that the entity should use the same cost formula for all inventories with the same nature and use to the entity; however, if the entity has inventories of various use and nature, using different cost formulas is justified (see IAS 2 (Para. 26 and 27) for a further explanation). On the other hand, AS-005 (Para. 111) states the use of weighted average cost as the main cost formula. It also permits the use of FIFO or last in, first out (LIFO) when the weighted average cost formula does not suit the nature of the company's activity, provided the company justifies the use of the chosen method and difference between the cost of goods sold as per the selected formula and that of goods sold according to the weighted average cost formula. The same disclosure is required for the cost of inventories at the end of a financial period.

IAS 2 (Para. 28-33) clearly explains the net realizable value. However, Paragraph 28 of IAS 2, which discusses the need to write down inventories below cost to net realizable value in certain situations, does not match any paragraph in AS-005. Even Paragraph 33 of IAS 2, which pertains to the new assessment of net realizable value in each subsequent period, does not have an equivalent in AS-005. Thus, if the economic circumstances change and there is clear evidence of an increase in the net realizable value, then the amount of the write-down is reversed. Paragraphs 29-32 of IAS 2 are similar to Paragraphs 115-119 in AS-005.

IAS 2's (Para. 34 and 35) recognition of inventory as an expense is more comprehensive in comparison to that in AS-005 (Para. 121). Paragraphs 34 and 35 include the following two additions. First, any reversal amount of inventory write-down emerging from an increase in net realizable value will be deemed a reduction in the amount of inventories recognized as an expense in the period the reversal occurred, which is not permitted by AS-005. Second, inventories that may be allocated to other asset accounts are recognized as an expense during the useful life of that asset. IAS 2 does not address the disclosure of inventories in the statement of financial position because it is explained in IAS 1, while Paragraph 124 of AS-005 discusses the disclosure of inventories.

The following disclosures required by IAS 2 (Para. 36) do not exist in AS-005: amount of inventories carried at fair value less costs to sell, the amount of inventories recognized as an expense during the period, amount of write-down of inventories recognized as an expense in the period according to Paragraph 34, amount of any write-down reversal deemed as reduction in the amount of inventories recognized as an expense in the period according to Paragraph 34, and circumstances or events that lead to the reversal of a write-down of inventories in accordance with Paragraph 34. Furthermore, paragraphs 38-39 of IAS 2 are overlooked in AS005 because they require the disclosing of information on costs that could be included in those of goods sold, which is recognized as an expense during the period. Paragraph (39) of IAS 2 describes costs recognized as an expense for raw materials and consumables, labor costs, and other costs that should be disclosed together with the amount of net change in inventories for the period. 


\subsection{Protocol for Data Collection}

The survey allowed for confidentiality and encouraged honesty by offering both the respondents and companies the option to maintain their identities as anonymous. The respondents of this survey are practicing accountants in Saudi Arabia in both listed and non-listed companies.

The survey was electronically mailed to 166 companies. The e-mail also stated that the respondents could forward the survey link to any practicing accountant they knew. A total of 44 questionnaires (response rate of $26.5 \%$ ) were returned, of which 40 were usable.

Table 1. Response to Questionnaire

\begin{tabular}{|l|l|}
\hline Number of Questionnaires Sent & 166 \\
\hline Number of Questionnaires Returned (Respond) & $44(26.5 \%)$ \\
\hline Number of Questionnaires Usable for Research & $40(90.91 \%)$ \\
\hline Number of Responses from Listed Companies & $17(42.5 \%)$ \\
\hline Number of Responses from Non-Listed Companies & $23(57.5 \%)$ \\
\hline
\end{tabular}

The questionnaire comprised three parts: (i) company details including name and sector as well as two questions providing indicators for company size (ii) whether a respondent attended training courses for international accounting standards, and (iii) technical questions related to IAS 2.

\section{Results}

This section details the research findings. Table (2) presents the ratios of "right," "wrong," and "do not know" responses to questions on the unique aspects of IAS 2 compared to AS-005.

About $60 \%$ of the accountants think that there are differences between the two concepts of fair value and net realizable value and only $30 \%$ were aware that land and other properties held for sale are considered part of inventories. In addition, 35\% were aware that the inventories of service providers included costs of revenues that have not yet been recognized. Of the total, $62.50 \%$ were aware that abnormal amounts of wasted material must be excluded from inventory cost. Similarly, $67.50 \%$ accountants answered correctly about the ability to include non-production overheads in inventory cost as long as they are incurred to bring inventories to their present location and condition in accordance with IAS 2 . Only $37.50 \%$ stated that the weighted average cost is not used to measure inventories of not-ordinarily interchangeable items. Furthermore, $40 \%$ were aware of the prohibition on using LIFO when estimating the cost of inventories and $20 \%$ knew that borrowing costs for inventories purchased on deferred settlement terms cannot be included in inventory costs. An optimistic ratio of $77.50 \%$ appeared to have knowledge about IAS 2's permission to use FIFO as a cost formula when assigning inventory costs. Moreover, $47.50 \%$ correctly answered the last question about IAS 2's permission to reverse the amount of inventory cost, which was written down before as a result of a comparison between inventory cost and net realizable value.

Table (2) shows that $52.27 \%$ answers are either "wrong" or "do not know," while $47.73 \%$ are right. This indicates that slightly more than half of the accountants may not be ready for the IFRS implementation, particularly IAS 2, because they lack related knowledge. Graph (1) presents the ratios of right answers for each survey question.

Table 2. Answers Table

\begin{tabular}{|l|l|c|c|c|c|c|c|}
\hline \multirow{2}{*}{ No. } & Question & \multicolumn{2}{l|}{ Right Answers } & \multicolumn{2}{l|}{ Wrong Answers } & \multicolumn{2}{l|}{ Don't Know Answers } \\
\cline { 2 - 8 } 1 & Count & Ratio & Count & Ratio & \multicolumn{2}{c|}{ Count } & Ratio \\
\hline 2 & $\begin{array}{l}\text { Differentiation between fair value and net } \\
\text { realizable value. }\end{array}$ & 24 & $60.00 \%$ & 10 & $25.00 \%$ & 6 & $15.00 \%$ \\
\hline 3 & $\begin{array}{l}\text { Inventories inclusion of land and other } \\
\text { properties held for sale. }\end{array}$ & 12 & $30.00 \%$ & 21 & $52.50 \%$ & 7 & $17.50 \%$ \\
\hline 4 & Service provider inventories. & 14 & $35.00 \%$ & 17 & $42.50 \%$ & 9 & $22.50 \%$ \\
\hline 5 & $\begin{array}{l}\text { Excluding the abnormal amounts of wasted } \\
\text { material from the cost of inventories. }\end{array}$ & 25 & $62.50 \%$ & 10 & $25.00 \%$ & 5 & $12.50 \%$ \\
\hline & $\begin{array}{l}\text { The ability to include non-production } \\
\text { overheads in the cost of inventories to the } \\
\text { extent they are incurred in bringing inven- } \\
\text { tories to present location and condition. }\end{array}$ & 27 & $67.50 \%$ & 7 & $17.50 \%$ & 6 & $15.00 \%$ \\
\hline
\end{tabular}


Table 2 (cont.). Answers Table

\begin{tabular}{|l|l|c|c|c|c|c|c|}
\hline 6 & $\begin{array}{l}\text { Cost formula concerning items that are } \\
\text { not ordinarily interchangeable. }\end{array}$ & 15 & $37.50 \%$ & 15 & $37.50 \%$ & 10 & $25.00 \%$ \\
\hline 7 & $\begin{array}{l}\text { The prohibition of (LIFO) in assigning } \\
\text { the cost of inventories. }\end{array}$ & 16 & $40.00 \%$ & 16 & $40.00 \%$ & 8 & $20.00 \%$ \\
\hline 8 & $\begin{array}{l}\text { Excluding borrowing costs from the costs } \\
\text { of inventories when the inventories are } \\
\text { purchased on deferred settlement terms. }\end{array}$ & 8 & $20.00 \%$ & 30 & $75.00 \%$ & 2 & $5.00 \%$ \\
\hline 9 & $\begin{array}{l}\text { The permission of using (FIFO) as a cost } \\
\text { formula in assigning the costs of invento- } \\
\text { ries. }\end{array}$ & 31 & $77.50 \%$ & 4 & $10.00 \%$ & 5 & $12.50 \%$ \\
\hline 10 & $\begin{array}{l}\text { Disclosing the carrying amount of inven- } \\
\text { tories carried at fair value less costs to } \\
\text { sell. }\end{array}$ & 19 & $47.50 \%$ & 10 & $25.00 \%$ & 11 & $27.50 \%$ \\
\hline $\begin{array}{l}\text { The permission of reversing the amount } \\
\text { of inventories' cost which was written- } \\
\text { down before as a result of comparing the } \\
\text { cost of inventories and the net realizable. }\end{array}$ & 19 & $47.50 \%$ & 7 & $17.50 \%$ & 14 & $35.00 \%$ \\
\hline
\end{tabular}

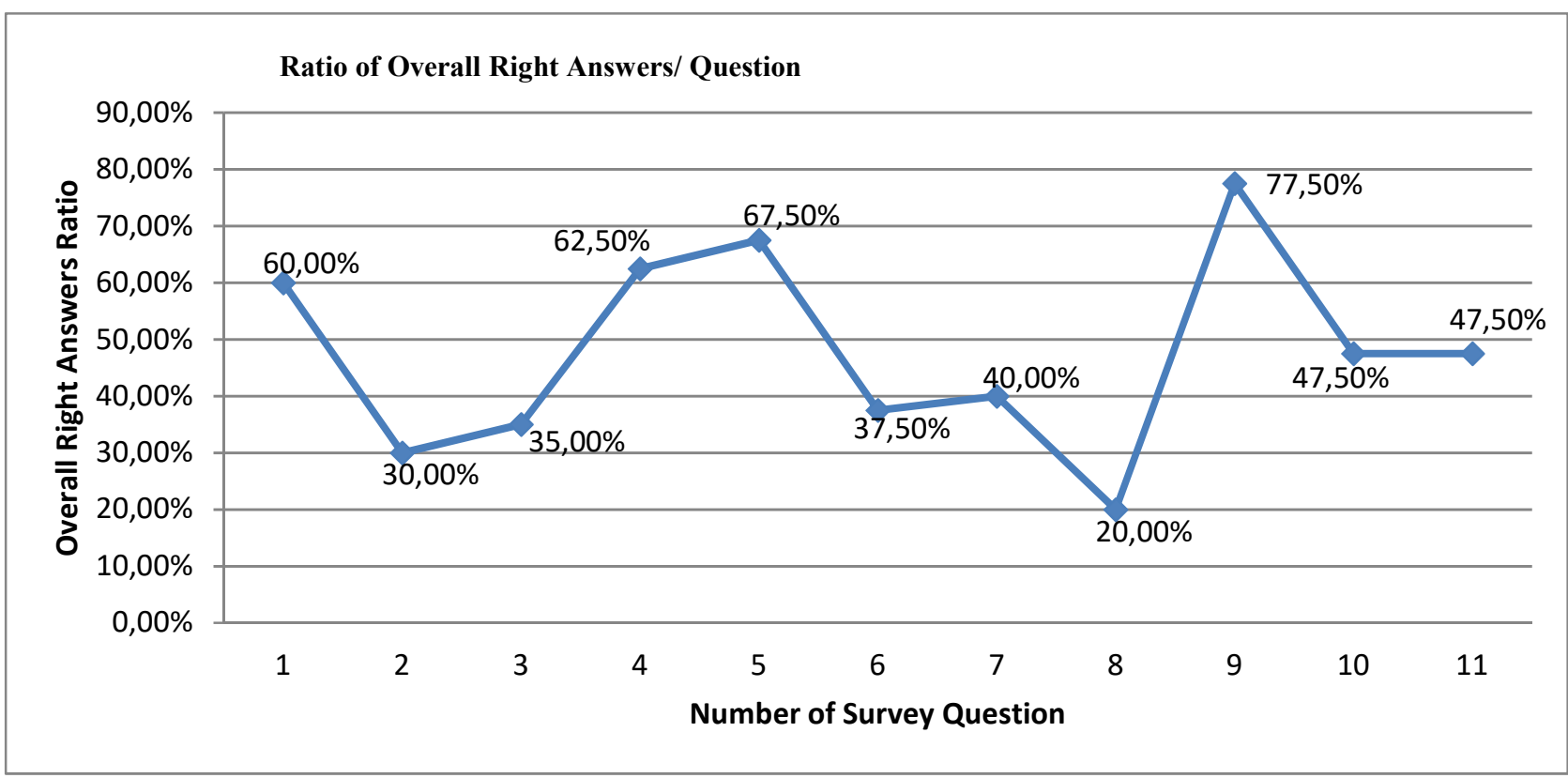

Graph 1. Ratio of Overall Right Answers/ Question

Table (3) presents the same questions that were subject to a categorization of the main concepts using the titles of IAS 2; the questions are derived from the paragraphs. The objective of the categorization is to assess the areas in which subjects demonstrate strength and weakness. These categories are classified using the following criteria: $>75 \%$ indicate a ready accountant, $50-75 \%$ denotes moderate readiness, and $<50 \%$ means low readiness.

Questions 1-3 in the survey are based on the first category and address the understanding of basic and important definitions associated with IAS 2. The results indicate that $41.67 \%$ of the answers are right answers (low readiness). Questions 4-8 address the second category: understanding costs included in and excluded from inventory costs according to IAS 2. Of the total, $50 \%$ are right answers (moderate readiness). Questions 6-9 are specific to the third category: understanding the terms and conditions related to cost formulas according to IAS 2. The right answers' ratio for this category is 51.67\% (moderate readiness). Questions 10 and 11 are based on categories four and five and each report $47.50 \%$ right answers (low readiness). The fourth category measures awareness of IAS 2 disclosure requirements and the fifth category estimates details of recording inventories in net realizable value according to IAS 2. Graph (2) demonstrates the ratios of right answers for each category. 
Table 3. Main Concepts Categories

\begin{tabular}{|c|c|c|c|c|}
\hline No. & Question & \multicolumn{2}{|c|}{ Categories } & $\begin{array}{l}\text { Ratio of Right Answers/ } \\
\text { Category }\end{array}$ \\
\hline 1 & $\begin{array}{l}\text { Differentiation between fair value and net realizable } \\
\text { value. }\end{array}$ & \multirow{3}{*}{ Cat.1 } & \multirow{3}{*}{$\begin{array}{l}\text { Understanding the basic } \\
\text { and important definitions } \\
\text { associated with IAS } 2 \text {. }\end{array}$} & \multirow{3}{*}{$41.67 \%$} \\
\hline 2 & $\begin{array}{l}\text { Inventories inclusion of land and other properties } \\
\text { held for sale. }\end{array}$ & & & \\
\hline 3 & Service provider inventories. & & & \\
\hline 4 & $\begin{array}{l}\text { Excluding the abnormal amounts of wasted material } \\
\text { from the cost of inventories. }\end{array}$ & Cat.2 & \multirow{3}{*}{$\begin{array}{l}\text { Understanding the costs } \\
\text { "included in" and "ex- } \\
\text { cluded from" the costs of } \\
\text { inventories according to } \\
\text { IAS } 2 \text {. }\end{array}$} & $50.00 \%$ \\
\hline 5 & $\begin{array}{l}\text { The ability to include non-production overheads in } \\
\text { the cost of inventories to the extent they are incurred } \\
\text { in bringing inventories to present location and condi- } \\
\text { tion. }\end{array}$ & & & \\
\hline 8 & $\begin{array}{l}\text { Excluding borrowing costs from the costs of invento- } \\
\text { ries when the inventories are purchased on deferred } \\
\text { settlement terms. }\end{array}$ & & & \\
\hline 6 & $\begin{array}{l}\text { Cost formula concerning items that are not ordinarily } \\
\text { interchangeable. }\end{array}$ & \multirow{3}{*}{ Cat.3 } & \multirow{3}{*}{$\begin{array}{l}\text { Understanding the terms } \\
\text { and condition related to } \\
\text { cost formulas according to } \\
\text { IAS } 2 \text {. }\end{array}$} & \multirow{3}{*}{$51.67 \%$} \\
\hline 7 & $\begin{array}{l}\text { The prohibition of (LIFO) in assigning the cost of in- } \\
\text { ventories. }\end{array}$ & & & \\
\hline 9 & $\begin{array}{l}\text { The permission of using (FIFO) as a cost formula in } \\
\text { assigning the costs of inventories. }\end{array}$ & & & \\
\hline 10 & $\begin{array}{l}\text { Disclosing the carrying amount of inventories carried } \\
\text { at fair value less costs to sell. }\end{array}$ & Cat.4 & $\begin{array}{l}\text { Awareness about IAS } 2 \\
\text { disclosure requirements. }\end{array}$ & $47.50 \%$ \\
\hline 11 & $\begin{array}{l}\text { The permission of reversing the amount of invento- } \\
\text { ries' cost which was written-down before as a result } \\
\text { of comparing the cost of inventories and the net real- } \\
\text { izable. }\end{array}$ & Cat.5 & $\begin{array}{l}\text { Understanding the details } \\
\text { of recording inventories in } \\
\text { net realizable value accord- } \\
\text { ing to IAS } 2 \text {. }\end{array}$ & $47.50 \%$ \\
\hline
\end{tabular}

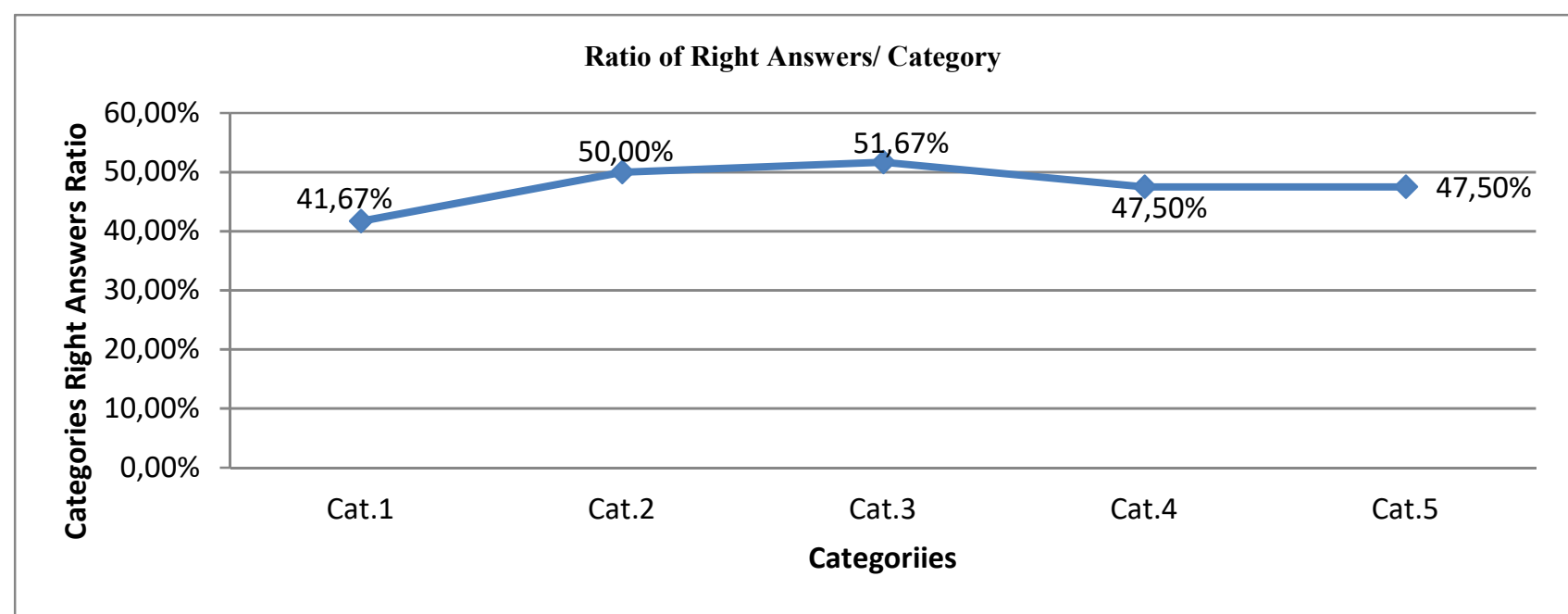

Graph 2. Ratio of Right Answers/ Category

These results reveal that accountants may not fully understand the basic definitions in IAS 2, that is, fair value, net realizable value, and inventories, of which fair value has been used in many other international accounting standards. In addition, accountants lack understanding of the details of recording inventories in net realizable value, which constitute a major part of IAS 2. They are also unaware of the disclosure requirements in IAS 2. About 50\% understand the costs included in and excluded from inventory costs according to IAS 2 and $51.67 \%$ are aware of the terms and conditions related to cost formulas according to IAS 2, which can be considered lower limits and indicate moderate readiness among accountants.

\subsection{Further Analysis}

In the light of the above analysis, it is worth further investigating whether the findings of this study vary by accountants' attendance at training sessions on requirements for IFRS implementation and by awareness of 
and familiarity with international accounting standards endorsed by SOCPA on its website. The latter is measured by whether accountants have visited SCOPA's website to source information on IFRS.

Table (4) presents the ratios of "right," "wrong," and "do not know" answers obtained after categorizing the accountants into two groups. The first group is based on whether accountants have attended training sessions on IFRS requirements and the second is about whether they have reviewed the international accounting standards on SOCPA's website. The results indicate that $40 \%$ of the accountants attended IFRS training sessions, while $60 \%$ did not. Of those who attended the training sessions (16 out of 40 accountants), $50 \%$ provided correct answers. On the other hand, of the total number of accountant who did not attend training sessions (24 out of 40 accountant), $46.21 \%$ offered right answers. Evidently, the two ratios are close to each other and thus, the effectiveness of training sessions is questionable. Furthermore, $60 \%$ of the accountants reviewed international accounting standards published on the SOCPA website and of these, $57.20 \%$ provided right answers. On the other hand, of the accountants who did not review the standards on the website (16 out of 40), 33.52\% offered right answers. These findings indicate that SOCPA's efforts to spread awareness and education about IFRS among practicing accountants are fruitful. This supplemental analysis shows that the contribution of SOCPA's website toward preparing accountants for IFRS adoption might be higher than that of other training sessions.

Table 4. Further Analysis Table

\begin{tabular}{|c|c|c|c|c|c|}
\hline & \multirow{3}{*}{ Overall Responses } & \multicolumn{4}{|c|}{ Responded Accountants } \\
\hline & & \multicolumn{2}{|c|}{ Training Courses } & \multicolumn{2}{|c|}{$\begin{array}{c}\text { International Accounting Standards at } \\
\text { SOCPA Website }\end{array}$} \\
\hline & & Attended & Not Attended & Reviewed & Not Reviewed \\
\hline $\begin{array}{l}\text { No. of Responded } \\
\text { Accountants }\end{array}$ & 40 & 16 & 24 & 24 & 16 \\
\hline Right Answers & $\begin{array}{c}210 \\
47.73 \% \\
\end{array}$ & $\begin{array}{c}88 \\
50.00 \% \\
\end{array}$ & $\begin{array}{c}122 \\
46.21 \% \\
\end{array}$ & $\begin{array}{c}151 \\
57.20 \% \\
\end{array}$ & $\begin{array}{c}59 \\
33.52 \% \\
\end{array}$ \\
\hline Wrong Answers & $\begin{array}{c}147 \\
33.41 \% \\
\end{array}$ & $\begin{array}{c}66 \\
37.50 \% \\
\end{array}$ & $\begin{array}{c}81 \\
30.68 \% \\
\end{array}$ & $\begin{array}{c}91 \\
34.47 \% \\
\end{array}$ & $\begin{array}{c}56 \\
31.82 \% \\
\end{array}$ \\
\hline $\begin{array}{ll}\text { Don't } & \text { Know } \\
\text { Answers } & \\
\end{array}$ & $\begin{array}{c}83 \\
18.86 \% \\
\end{array}$ & $\begin{array}{c}22 \\
12.50 \% \\
\end{array}$ & $\begin{array}{c}61 \\
23.11 \% \\
\end{array}$ & $\begin{array}{c}22 \\
8.33 \% \\
\end{array}$ & $\begin{array}{c}61 \\
34.66 \% \\
\end{array}$ \\
\hline
\end{tabular}

\section{Conclusions}

This study presented evidence on the readiness of practicing accountants in Saudi Arabia regarding IFRS implementation. Using an electronic survey, the analysis provided insights for professional and interested parties as well as official bodies that set related standards in Saudi Arabia to assume the necessary steps to prepare accountants for the IFRS implementation. The survey included questions on the unique aspects of IAS 2 as an indicator for the overall readiness of accountants regarding the mandatory implementation of IFRS. The first conclusion to be drawn is that a proportion of accountants may not be ready for the IFRS implementation. More specifically, their lack of knowledge regarding certain IAS 2 requirements is evident and this raises concerns about their readiness to implement more complicated IFRS, some of which have no comparable local financial accounting standard.

In this study, the accountants demonstrated lack of readiness regarding the following aspects: basic definitions associated with IAS 2, details of recording inventories in net realizable value according to IAS 2, and awareness of IAS 2 disclosure requirements. They show moderate readiness concerning terms and conditions related to cost formulas and costs included in and excluded from inventory cost according to IAS 2.

Further, the results reveal that the effectiveness of training sessions is questionable given that the difference between the ratio of right answers for accountants who attended IFRS courses and for those who did not is not as large. In addition, the data show that SOCPA's efforts to spread awareness and education about IFRS using its website have been successful. In fact, the contribution of SOCPA's website toward preparing accountants for the IFRS adoption is possibly greater than that of the training sessions.

Despite the implications of our findings, this study is not free from limitations. First, a research question generally mandates the type of questions to be asked and the questions presented in this study are rather direct. Another limitation is the arbitrariness of the criteria used to assess accountants' strengths and weaknesses regarding IAS 2's main concepts. Moreover, the use of various criteria may lead to inconsistent results. Finally, and a major limitation of this study is the need for a larger sample. 
Thus, it will be interesting for future research to examine the development of accountants' skills regarding IFRS requirements in Saudi Arabia, especially since IFRS took effect on January 1, 2017, for all listed companies. In theory, all accountants in Saudi Arabia should be aware of and implement IFRS that are related to the activities of their entities. This investigation can also be extended to auditors' readiness regarding the mandatory implementation using questionnaires and importantly, scenarios for data collection.

\section{Acknowledgements}

This paper is a substantially improved version of the paper prepared by the first author as a research project for a Research Project in Accounting course taught and supervised by the second author. Both authors worked on the revised version. The authors thank Mr. Suliman Abutayeh, CPA as well as Abdulmalik Al-Hogail, $\mathrm{PhD}$, Saudi CPA, and Chief Financial Officer at Al Faisaliah Group for evaluating the questionnaire. The authors also acknowledge suggestions by Assistant Secretary General at SOCPA, Abdulrahman Al-Razeen $\mathrm{PhD}$, for the IFRS section. All remaining errors are our own.

\section{References}

1. Abutayeh, Suliman, (2013). "The Project of Developing International Accounting Standards: Reviewing the International Accounting standards of Inventories (IAS 2)". Unpublished Report Submitted to Saudi Organization for Certified Public Accountants (SOCPA).

2. Agyei-Mensah, B. K. (2013). "Adoption of international financial reporting standards (IFRS) in Ghana and the quality of financial statement disclosures". International Journal of Accounting and Financial Reporting, 3(2), $269-286$.

3. Al-Adeem, K. (2015). "The extent to which International Financial Accounting Standards as an international product fits in harmony with local communities: evidence from accounting research." A paper presented at the 9th forum for the Gulf Cooperative Council for Accounting and Auditing Organization (GCCAAO). Bahrain, Manama. 6-7/5/2015. Available:http://www.gccaaoforum.org/photoGa lary/comp/\%D8\%A7\%D9\%88\%D8\%B1\%D8\%A7\%D9\%82\%20\%D8\% B9\%D9\%85\%D9\% 84\%20\%D9\%85\%209/Dr.\%20Khalid\%20AlAdeem.pdf

4. Al-Adeem, K. (2017b). Contributions of Gulf Cooperation Council for Accounting and Auditing Organization's (GCCAAO) Attempts Unifying Accounting Practices and Standards in Enriching Accounting Thought: Analysis and Evaluation. Accounting Thought Journal, 21, 1 (2), 533-566.

5. Al-Adeem, Khalid, (2013). "The Project of Developing International Accounting Standards: International Accounting standards of Inventories (IAS 2)". Unpublished Report Submitted to Saudi Organization for Certified Public Accountants (SOCPA).

6. Al-Adeem, K. (2017a). “A need to theorize corporation: An accounting perspective." International Journal of Accounting Research, 5(2), 166.

7. Al-Adeem, Khalid R. and Fogarty, Timothy J. (2010). Accounting Theory: A Neglected Topic in Academic Accounting Research, LAP LAMBERT Academic Publishing AG \& Co. KG Theodor-Heuss-Ring 26, 50668 Köln, Germany.

8. Alali, F. and Cao, L. (2010). "International financial reporting standards — credible and reliable? An overview." Advances in Accounting, 26(1), 79-86.

9. Alali, F. A. and Foote, P. S. (2012). "The value relevance of international financial reporting standards: Empirical evidence in an emerging market." The international journal of accounting, 47(1), 85-108.

10. Alhamoudi, R. (2017). The Ability of Accountants in Saudi to Apply the International Accounting Standard Impairment of Assets IAS 36: An Empirical Investigation. May. Unpublished Accounting Research Project for the Course "Research Project in Accounting”. College of Business Administration, King Saud University, Riyadh, Saudi Arabia.

11. Almowash, S. (2015). The Extent to which Practicing Accountants in Saudi Arabia Ready for Implementing IFRS 41: An Explanatory Study. December. Unpublished Master Accounting Research Project for the Course. College of Business Administration, King Saud University, Riyadh, Saudi Arabia.

12. Alsalamah , A. (2017). Accountants' Readiness in Implementing IFRS13: Evidence from Saudi Arabia. May. Unpublished Master Accounting Research Project for the Course. College of Business Administration, King Saud University, Riyadh, Saudi Arabia.

13. Ball, R. (2006). "International Financial Reporting Standards (IFRS): pros and cons for investors". Journal of Accounting and Business Research, 36 (1), 5-27.

14. Barth, M. E., Landsman, W. R., and Lang, M. H. (2008). "International accounting standards and accounting quality." Journal of Accounting Research, 46(3), 467-498.

15. Belkaoui, (1995). The Cultural Shaping of Accounting. CT, Westport: Quorum Books.

16. Bradshaw, M., Callahan, C., Ciesielski, J., Gordon, E. A., Hodder, L., Hopkins, P. E.,... and Stocken, P. (2010). Response to the SEC's proposed rule - Roadmap for the potential use of financial statements prepared in accordance with International Financial Reporting Standards (IFRS) by US issuers. Accounting Horizons, 24(1), 117-128.

17. Buchanan, F. R. (2003). "International accounting harmonization: Developing a single world standard." Business Horizons, 46(3), 61-70. 
18. Camfferman, K. and Zeff, S.A. (2007). Financial Reporting and Global Capital Markets: A History of the IASC (1973-2000). Oxford University Press.

19. Cascino, S. and Gassen, J. (2012). "Comparability effects of mandatory IFRS adoption, SFB 649 discussion paper”, No. 2012-009 < Available via: https://www.econstor.eu/handle/10419/56682 last accessed 8/3/2017>

20. Chatfield, M., (1977). A History of Accounting Thought (Revised edition). Huntington, NY: Robert E. Krieger Publishing Company.

21. Chua, Y. L., Cheong, C. S., and Gould, G. (2012). "The impact of mandatory IFRS adoption on accounting quality: Evidence from Australia." Journal of International Accounting Research, 11(1), 119-146.

22. Cowan, T. K. (1968). "A pragmatic approach to accounting theory." The Accounting Review. Jan. 43 (1): $94-100$.

23. Clark, T. (1996). "Mechanisms of corporate rule." In Jerry Mander and Edward Goldsmith (Eds). The Case Against the Global Economy and for a Turn toward the Local. CA, San Francisco: Sierra Club Books

24. Ding, Y., Jeanjean, T., and Stolowy, H. (2005). "Why do national GAAP differ from IAS? The role of culture." The International Journal of Accounting, 40(4), 325-350.

25. DR Scott. (1929). "Conservatism in inventory valuation." The Accounting Review. Papers and Proceedings of the Tenth Annual Meeting of the American Association of University Instructors of Accounting, 1(1), 18-22.

26. Elias, N. (2012). "Discussion of the impact of mandatory IFRS adoption on accounting quality: Evidence from Australia.” Journal of International Accounting Research, 11(1), 147-154.

27. Erickson, D., Esplin, A., and Maines, L. A. (2009). "One world-One accounting." Business horizons, 52(6), $531-537$.

28. Florou, A., and Pope, P. F. (2012). "Mandatory IFRS adoption and institutional investment decisions." The Accounting Review, 87(6), 1993-2025.

29. Gray, S. J. (1988). "Towards a theory of cultural influence on the development of accounting systems internationally." ABACUS, 24 (1), 1-15.

30. Haas, J. (2013). "Towards a comprehensive appraisal of global accounting harmonization: About the "desirability" of IFRS-A comment on Ramanna's 'The international politics of IFRS harmonization'." Accounting, Economics and Law, 3(2), 53-68.

31. Haller, A., and Wehrfritz, M. (2013). "The impact of national GAAP and accounting traditions on IFRS policy selection: evidence from Germany and the UK”. Journal of International Accounting, Auditing and Taxation, 22(1), 39-56.

32. Holder, A. D., Karim, K. E., Lin, K. J., and Woods, M. (2013), "A Content Analysis of the Comment Letters to the FASB and IASB: Accounting for Contingencies," Advances in Accounting, Incorporating Advances in International Accounting, 29, 134-153.

33. Hopwood, A. G. (1987). "The archeology of accounting systems.” Accounting, Organizations and Society, 12 (3), 207-234.

34. Iatridis, G. (2010). "International Financial Reporting Standards and the quality of financial statement information." International Review of Financial Analysis, 19 (3), 193-204.

35. International Accounting Standard Board (IASB) (2003). International Accounting Standard 1 (IAS 1), Presentation of Financial Statements.

36. International Accounting Standard Board (IASB) (2003). International Financial Reporting Standard 1 (IFRS 1), First-time Adoption of International Financial Reporting Standards.

37. Joshi, P. L., Bermser, W. G. and Al-Ajmi, J. (2008). Perceptions of accounting professionals in the adoption and implementation of a single set of global accounting standards: Evidence from Bahrain. Advances in Accounting, Incorporating Advances in International Accounting, 24, 41-48.

38. Karim, R.A.A (2001) "International accounting harmonization, banking regulation, and Islamic banks." The International Journal of Accounting 36, 169-193

39. Königsgruber, R. (2010). “A political economy of accounting standard setting.” Journal of Management \& Governance, 14(4), 277-295.

40. Kosarkoska, D and Mircheska, I. (2012), “The Main Process In the International Financial Reporting at the Beginning of 21 st Century". Procedia - Journal of Social and Behavioral Sciences 44, 241-249.

41. Kotlyar, J. (2008). "The advent of the international financial reporting standards: a catalysteor changing global finance." Journal of International Affairs, 62 (1),238-321.

42. Lehman, G. (2005). "A critical perspective on the harmonisation of accounting in a global world." Critical Perspectives on Accounting. 16: 975-992.

43. Li, Y. (2013) “Does Mandatory IFRS Adoption Facilitate Financial Market Integration?” (January 8, 2013). CAAA Annual Conference 2013. Available at SSRN: https://ssrn.com/ab-

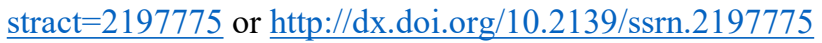

44. Littleton, A. C. (1966). “Accounting Evolution to 1900.” New York, NY: Russell and Russell.

45. Madsen, P. E. (2013). "Evaluation accounting standard: a comment on Ramanna's ' International politics of IFRS harmonization'." Accounting, Economics and Law, 3(2), 77-92..

46. Merino, B. D. (1993). "An analysis of the development of accounting knowledge: A pragmatic approach." Accounting, Organizations and Society, 18 (2/3), 163-185.

47. Monday, S. E. (2009) "IAS 16 and the Revaluation Approach: Reporting Property, Plant and Equipment at Fair Value." University of Tennessee Honors Thesis Projects. htp://trace.tennessee.edu/utk_chanhonoproj/1297 
48. Odia,. J.O and Ogiedu, K.O. (2013), "IFRS adoption: Issues, challenges and lessons for Nigeria and other adopters". Mediterranean Journal of Social Sciences, 4(3),389-399

49. Ordelheide, D. 2004. The politics of accounting: A framework. In Leuz, C., Pfaff, D., and Hopwood, A. G. (Eds.). The Economics and Politics of Accounting: International Perspectives on Research Trend, Policy, and Practice, Oxford: Oxford University Press, 269-284.

50. Parker, P. J. L. (2014). “Financial Markets and the ACI Dealing Certificate 3I0-012” (2 ${ }^{\text {nd }}$ ed.). Electronically published: Lulu.com.

51. Posner, E. (2009). "Making rules for global finance: transatlantic regulatory cooperation at the turn of the millennium." International Organization, 63, 665-699

52. Posner, E. (2010). "Sequence as explanation: The international politics of accounting standards." Review of International Political Economy. 17(4), 649-664.

53. Previts, G. J. and Merino, B. D. (1998). “A History of Accountancy in the United States.” Columbus, OH: Ohio State University Press.

54. Ramanna, K. (2013). "The international politics of IFRS harmonization.” Accounting, Economics and Law, 3(2), 1-46.

55. Ramanna, K. and Sletten, E. (2009), "Why do countries adopt international financial reporting standards?" Harvard Business School Accounting \& Management Unit, Working Paper No. 09-102.

56. Saito, S. (2013). The international politics of IFRS harmonization: A Comment." Accounting, Economics and Law, 3(2), 47-52.

57. Saudi Organization for Certified Public Accountants (SOCPA). SOCPA Project for Transition to International Accounting \& Auditing Standards, available at: http://socpa.org.sa/Socpa/About-Socpa/SOCPA-Projects.aspx?lang=en-us 58. Soderstrom, N. S., and Sun, K. J. (2007). "IFRS adoption and accounting quality: a review." European Accounting Review, 16(4), 675-702.

59. Stent, W., Bradbury, M. and Hooks, J. (2010).” IFRS in New Zealand: effects on financial statements and ratios." Pacific Accounting Review, 22 (2).

60. Tinker. Tony (2004). "The Enlightenment and its discontents: Antinomies of Christianity, Islam and the calculative sciences." Accounting, Auditing \& Accountability Journal, 17(3), 442-475

61. Tsunogaya, N. (2016). Issues affecting decisions on mandatory adoption of International Financial Reporting Standards (IFRS) in Japan. Accounting, Auditing \& Accountability Journal, 29(5), 828-860.

62. Tyrrall, D., Woodward, D., and Rakhimbekova, A. (2007). The relevance of International Financial Reporting Standards to a developing country: Evidence from Kazakhstan. The international Journal of accounting, 42(1), 82-110.

63. Yilmaz, E and Gelmedi, O. (2012). Assessing international accounting harmonization using Izomorfism." $2^{\text {nd }}$ International Symposium on Sustainable Development. June 8-9 2010, Sarajevo. Available at http://eprints.ibu.edu.ba/298/ last visit $8 / 6 / 2017$

64. Yip, R. W. Y. and Young, D. (2012). “Does mandatory IFRS adoption improve information comparability?”. The Accounting Review Journal, 87 (5), 1767-1789.

65. Zéghal, D., Chtourou, S., and Sellami, Y. M. (2011). An analysis of the effect of mandatory adoption of IAS/IFRS on earnings management. Journal of International Accounting, Auditing and Taxation, 20(2), 61-72.

66. Zehri, F. and Chouaibi, J., (2013). "Adoption determinants of the International Accounting Standards IAS/IFRS by the developing countries". Journal of Economics, Finance and Administrative Science, 18 (35), 56-62.

\section{Appendix}

Greetings,

As it is well known by you, the board of directors of the Saudi Organization for Certified Public Accountants (SOCPA) has decided to implement the international accounting standards after the completion of endorsing by the organization, as to be the closer date for the implementation on the financial statements prepared for financial periods beginning from 01-01-2017, for the enterprises listed on the stock market. For other facilities, the earliest date for implementation shall be for the financial statements prepared for periods beginning on 01-01-2018. The Researcher is conducting a study on the readiness of accountants in Saudi Arabia to implement the international accounting standard of inventories (IAS 2), to complete the requirements of obtaining a master's degree at the Faculty of Business Management/ Accounting Department at King Saud University. Because we believe that you wish to contribute to the efforts in the success of the transformation project to the international accounting standards, kindly answer all the questions of the following survey. We assure you that this questionnaire is for the purposes of scientific research only and that the answers received will remain confidential.

* Required field

Name of the company (optional): 
The sector which the company belongs to: *

The company I worked in is:

- Listed company on the Saudi stock market

- Not a listed company on the Saudi stock market

The estimated number of accountants employed in the company:

- Less than 20

- From 20-50

- From 51-100

- More than 100

Personal Data:

Name (optional):

Jop postion:

Qualification:

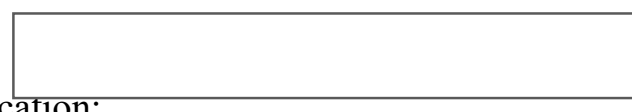

- B.Sc.

- Master Degree.

- Ph.D.

Scientific Specialization:

- Accounting

- Business Management

- Other

Professional Certification:

- SOCPA

- CPA

- None

- Other

Years of Experience:

- Less than 5 years

- From 5-10 years

- From 10-15 years 
- More than 15 years

You have attended a training course on international accounting standards.

- Yes

- No

You have familiarized yourself with the international standards adopted by the Saudi Organization for Certified Public Accountants which are included in its website.

- Yes

- No

You think that the company you work in will transfer smoothly to the International accounting standards.

- Yes

- No

- I Don’t Know

The Survey:

1- There is no difference between the concept of fair value and the concept of net realizable value.

- Yes

- No

- I Don’t Know

2- Under IFRS, lands and other properties held for resale are considered to be within inventories.

- Yes

- No

- I Don’t Know

3- In Accordance with International Accounting Standards, in the case of a service provider; inventories include the costs of the service, for which the entity has not yet recognized the related revenue.

- Yes

- No

- I Don’t Know

4- In accordance with International Accounting standards, the costs of the abnormal amounts of wasted materials is part of the costs of inventories.

- Yes

- No

- I Don't Know

5- In Accordance with the International Accounting standards, the Accountant can include non-production overheads in the costs of inventories only to the extent that they are incurred in bringing the inventories to their present location and condition. 
- Yes

- No

- I Don’t Know

6- In Accordance with the International Accounting Standards, the company sets the cost of inventories of items that are not ordinarily interchangeable by using weighted average cost formula.

- Yes

- No

- I Don’t Know

7- The International Accounting Standards allow the use of last-in first-out (LIFO) cost formula to assign the inventories costs as long as the justifications are disclosed.

- Yes

- No

- I Don’t Know

8- A company has purchased inventories, on a deferred settlement terms that consequent an interest therefor, this interest is part of the cost of inventories.

- Yes

- No

- I Don’t Know

9- A company has used the First-in First-out (FIFO) cost formula in the calculation of the inventories costs instead of the weighted average cost formula, the behavior of this company is a clear violation of the international accounting standards.

- Yes

- No

- I Don’t Know

10- The disclosure of the carrying amount of inventories carried at fair value less costs to sell is considered to be optional according to the international accounting standards.

- Yes

- No

- I Don't Know

11- The International Accounting Standard for Inventories allows increasing the value of the goods by the extent that it has been previously reduced as a result of the annual comparison between the cost of goods and the net realizable value.

- Yes

- No

- I Don’t Know 